\title{
Growing households' income through non-timber forest products
}

\author{
Sudaryanto $^{1}$, Gemilang Khairinissa ${ }^{2}$, Suyud Warno Utomo ${ }^{3,4}$, and Tarsoen Waryono ${ }^{5}$ \\ ${ }^{1}$ Magister Program, School of Environmental Science, Indonesia University, Salemba Campus, Jakarta - Indonesia, \\ ${ }^{2}$ Indonesia Climate Change Trust Fund (ICCTF), Gd. Lippo Kuningan 1t. 15, Jakarta - Indonesia \\ ${ }^{3}$ Environmental Science Program, School of Environmental Science, Indonesia University, Salemba Campus Jakarta - Indonesia \\ ${ }^{4}$ Department of Environmental Health. Faculty of Public Health, UI, Depok Campus Jakarta - Indonesia \\ ${ }^{5}$ Department of Geography, Faculty of Mathematics and Nature Science, University of Indonesia
}

\begin{abstract}
Population pressure to the forest is caused by the difficulty in fulfilling their needs. The condition then leads to unequal access to the resources and threatens the forest. A system of community forest management are necessary (Svendsen, 2009, Cheng, 2011, Tiwari, 2014). This study aims to evaluate the economic impact of coffee agroforestry and tourism businesses in Tugu Utara village, Cisarua, Bogor regency. This is quantitative research. The data colecting method used is suvey of saturated sampling method. The data are sells of cherry coffee, income from tourism activities and households' expenses in 2018. The households income and expenses data were analyzed to find the contribution of households expenses. The results of the study showed that the expenses of households in 2018 was IDR 2,875,000 / family / month. The average of households' income from the forest-based tourism activities is IDR 1,115,600 / household / month and the income from cherry coffee sales in 2018 is IDR 1,770,800 / family / month. The percentage of monthly income compared to households' expenses is $100 \%$. This study concludes that the needs of household can be fulfilled from the coffee agroforestry income added with income from the forest-based tourism activities.
\end{abstract}

Keywords: coffee agroforestry, forest management, NTFP income, population pressure, restoration

\section{INTRODUCTION}

The environmental pressure can be resulted from many factors which one of them is population $[1,2]$. According to Daldjoeni [3], population pressure to the environment is mostly caused by the difficulties of people in coping with their current population and struggling to survive as the population growth rate in a particular area is unequal with its carrying capacity. This condition then leads to unequal access to the resources and threatens the forest. As such, planning, implementing, and monitoring the management of forests with a system of community forest management are necessary [4-7]. In Tugu Utara village, there is pressure to the forests by farmers of Tugu Utara village who have low incomes which is below the Bogor Regency per capita income of IDR 1,750,000,- [8,9]. Due to the population growth, they were dependent on forests resources as well as cleared the forests to make agricultural lands as their source of income. This situation, however, changed after the forests were shifted into protected forests that conserve water and soil resources as by the time the farmers are prohibited to access the forests resources for their own benefits [10, 11]. Accordingly, management of forest with a system of community forest management has been implemented in Tugu Utara village to maintain the people pressure to the forest. The farmers make use of the forests as coffee and other agricultural species plantations by implementing an agroforestry system to be the new source of their income $[12,13]$.

\section{MATERIAL AND METHODS}

The aim of this study is, thus, to evaluate the economic impact of community forest management on the agroforestry coffee production and eco-tourism business to meet households' economic needs [14-17]. The study was conducted in Tugu Utara village, Cisarua District, Bogor Regency. This study uses a quantitative approach and the impact of increasing income is measured through surveys on the families' income and expenditure. There are 18 farmers are interviewed during this study. Those farmers live in Cibulao, Rawa Gede, Pondok Rawa, and

Corresponding author: suyudwarno@gmail.com 
Cisuren community group. The collected data were analyzed using descriptive and narrative methods by emphasizing on the case discussion to provide a thorough understanding of the actual context of the situation [18]. The data, especially the household income and expenditure, are processed by using the descriptive analysis method. Revenue from the coffee cultivation (NTFP) is calculated from the total income of the cherry coffee sales and production costs, including the raw materials, labor, overhead costs, and social costs [19].

\section{RESULT AND DISCUSSION}

Tugu Utara village has a varying altitude of $800-1,700$ above sea level. The area is 1,703 ha which consists of 610 ha of Hutan Pangkuan Desa (one of community forest management models developed in Indonesia) and 70 ha of protected forest. The village is inhabited by 11,048 people consisting of 5,691 men and 5,257 women, added into the total of 3,150 households [20]. From these numbers, some of them are having the forests as their main source of income and daily needs as they grow vegetables, fruits, and coffee, as well as take woods and grass from the forests, while the others are having used of some particular areas from the forest. This includes utilizing water originated from the forests as the source of clean water and drinking water produced by BUMDes (village-owned enterprise) Tugu Utara village, developing a bee farm in the forest to sell honey to the tourists, advancing the environmental services that is supported by local forest community called Lembaga Masyarakat Desa Hutan (LMDH), and also encouraging the forests' nature attraction such as climbing Kencana mountain, bird-watching tour, cycle, tour to the waterfalls, go to the honey bee farm, tour to the tea gardens, and tour to the coffee plantation.

After the 1998 reformation, there was illegal logging in Tugu Utara HPD where the forest became damaged and landslide was occurred. The activity of planting coffee on landslide land has been started since 2000 by Cibulao village farmers. The coffee agroforestry system at Tugu Utara HPD officially began in 2009 by the stateowned company Perum Perhutani with a system of Community Based Forest Management (PHBM) [21]. Forests play an important role for the population, especially the poor who live in the villages of tea plantations near the forest, to claim additional income and reduce household costs. Because of its status as production forest and conservation forest, the community conducts legal economic activities by utilizing Non-Timber Forest Products (NTFPs). In addition, HPD also produces ecosystem services for the population, namely being a source of clean water for Clean Water Management/Drinking Village (PAMDes) Tugu Utara, cool and harmonious air, natural tourism, and a comfortable micro climate. Nevertheless there are also those who grow vegetables and grass.

Farmers who participate in coffee agroforestry activities can begin to have the harvest after coffee grows well and produces fruit several years later [22-24]
Table 1. Percentage of meeting economic needs from income from NTFPs

\begin{tabular}{|c|c|r|r|r|}
\hline No & Sample & $\begin{array}{c}\text { Household } \\
\text { Monthly } \\
\text { Income in } \\
2018 \text { (IDR) }\end{array}$ & $\begin{array}{c}\text { Household } \\
\text { Expenses } \\
\text { in 2018 } \\
\text { (IDR) }\end{array}$ & $\begin{array}{c}\text { Percentage } \\
\text { of income } \\
\text { vs } \\
\text { expenditure } \\
\text { (\%) }\end{array}$ \\
\hline 1 & A & $3,250,000$ & $3,000,000$ & 100 \\
\hline 2 & B & $3,916,667$ & $3,000,000$ & 100 \\
\hline 3 & C & $3,916,667$ & $3,000,000$ & 70 \\
\hline 4 & D & $3,916,667$ & $3,000,000$ & 100 \\
\hline 5 & E & $3,916,667$ & $3,000,000$ & 100 \\
\hline 6 & F & $3,916,667$ & $3,000,000$ & 100 \\
\hline 7 & G & $3,916,667$ & $3,000,000$ & 62 \\
\hline 8 & H & $3,916,667$ & 3.000 .000 & 100 \\
\hline Total & & 34.637 .500 & 34.500 .000 & 100 \\
\hline $\begin{array}{l}\text { The average per } \\
\text { month }\end{array}$ & 2.886 .458 & 2.875 .000 & \\
\hline
\end{tabular}

Source: From the interview in 2018

Respondents are known as KTH (Forest Farmers Groups) members and LMDH (Forest Village Community Organization) members who have several activities as well as a source of income. Farmer's main income comes from working in the tea garden while for agroforestry coffee harvests which is in the forest, and tourism businesses as a side business. On Sundays and holidays, community group and Perhutani Officers manage bicycle tours. The KTH Cibulao Hijau also develops coffee-based agro tourism. They made a coffee processing business, tourism package and homestay. This business has been growing because of the name of the famous Cibulao coffee since winning the specialty coffee competition in Nangroe Aceh Darussalam in 2016, and supported by the ease of communication networks and easy delivery of goods. The one, who has retired as a tea plantation worker, currently besides being a coffee farmer has also built a homestay in her house. Six other people besides being coffee farmers, also work at Wonderful Citamiang natural tourism center of Tugu Utara village.

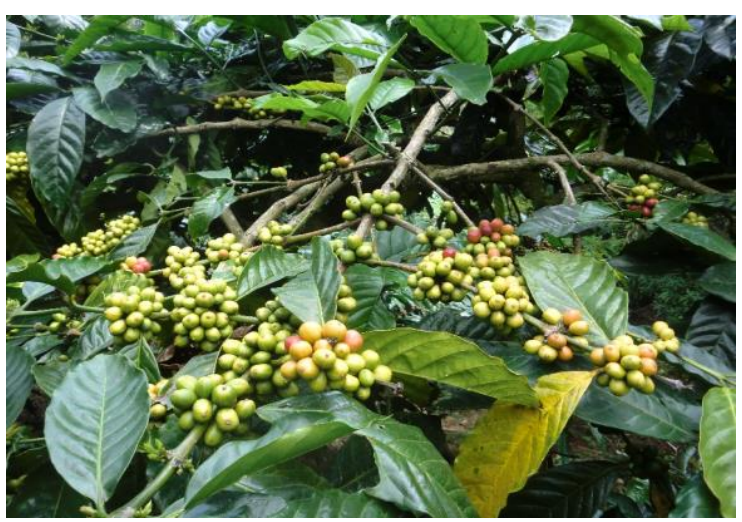

Figure. 1. Robusta coffee in July 2018 
Coffee that has been planted since 2009 and the next few years has now produced dense fruit. The types of coffee planted by farmers are robusta and arabica. The type of arabica harvest is quite long, while for the type of robusta the harvest period is around 1 month, namely July-August.

Coffee harvested is coffee that is ripe, so the quality of the coffee is very good. Harvesting of Robusta coffee is done every week, where farmers can harvest it 3-4 times until the coffee is all ripe and the total harvest. Coffee beans are separated by a specially designed coffee peeler. The results of the coffee beans are then dried in the hot sun to dry. The right process is that farmers will sort coffee beans into several categories based on their quality, namely super quality, medium quality and ordinary quality. Super quality is coffee with seeds that are intact and suitable for sale to be green beans to fulfill subscription cafe orders.

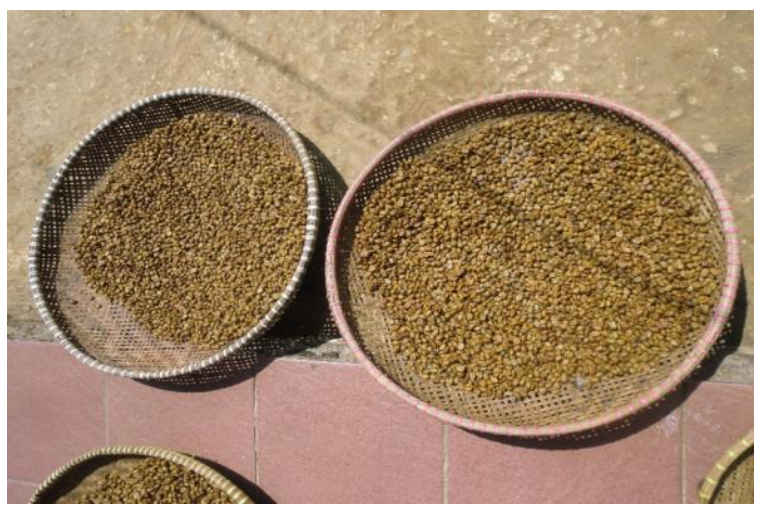

Figure. 2. Robusta coffee in July 2018

The quality standard of coffee beans is determined based on the type, processing method, defect value and moisture content agreed upon by the International Coffee Organization (ICO) in 2002 through the ICO Council session and produced resolution No. 407. During this time in Tugu Utara village, the separation of seeds or sorting of coffee beans was still done manually, which is one by one. The first step in the separation of these coffee beans is that the coffee will be selected broken and damaged then the best one will be selected while the rest is medium quality coffee. Separation of manual coffee beans like this takes a long time and requires a lot of energy. Therefore, it is very necessary to have a sorting machine that can speed up this process which is then referred to as a coffee peeler machine.

If coffee is sold in the form of cherries, the price ranges from IDR. 7,000 - IDR. 8,000/ kg. However, farmers can get a better price if the coffees are sorted first. Farmers with their family member need to work together to do this sorting. But in fact the results of the selection have not reached the standard up to 6 grades because the sorting results are still limited to only Super and Premium coffee beans. Super green bean arabica coffee is sold at IDR. $120,000 / \mathrm{kg}$ while the premium price is IDR. 85,000/ kg. This price is different for Robusta coffee where the type of robusta coffee, namely super green bean, is sold at IDR. 75,000/ kg while the premium is priced at IDR. 50,000 / kg. However, sometimes there is also some coffee that is damaged so it must be separated and sold at a much cheaper price, namely for arabica at a price of IDR. $45,000 / \mathrm{kg}$ and robusta IDR. 20,000/ kg. This price is the price in local market. From the yield, if it is sold in the form of cherry then it is calculated and deducted by production costs, it will give an average profit of IDR. 21,250,000 / household / year or IDR. 1,770,800 / household / month (Table 1).

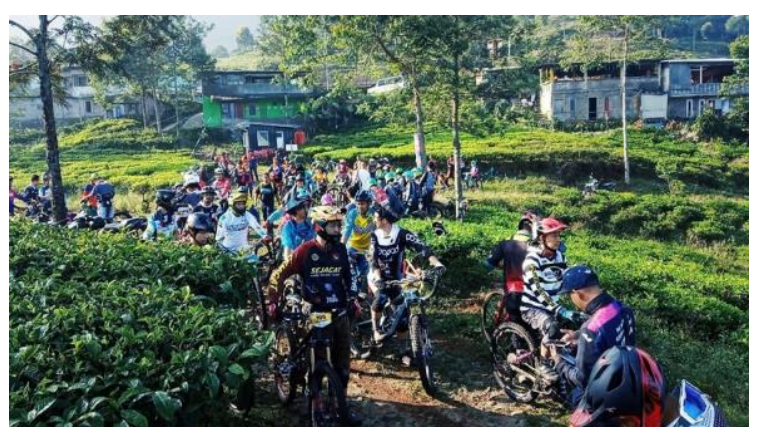

Figure. 3. The Fun Bike (Photo by Kiryono)

Bicycle tourism is an activity developed by the Cibulao village Farmers Group where they operate, in collaboration with Perhutani. This is due to the mountain bike lane inside the HPD area. From this tourism activity, profit sharing is carried out between tourism managers and Perhutani based on existing rules and agreed by both parties.

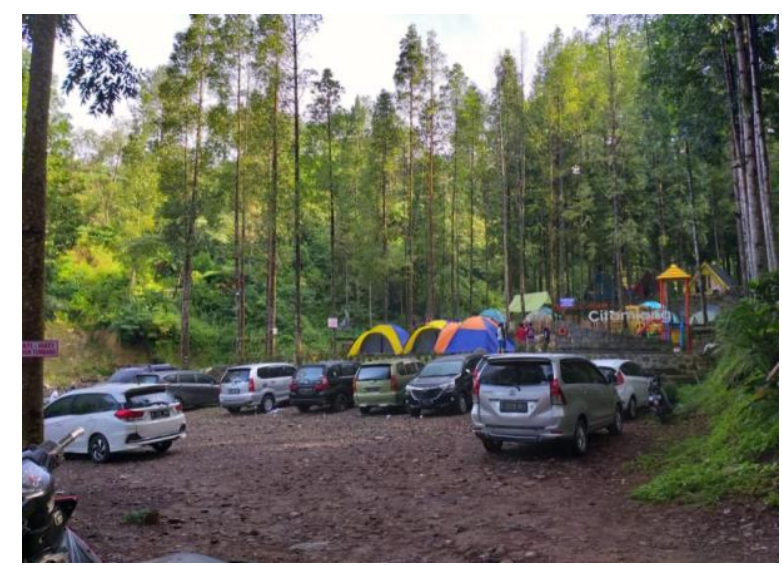

Figure. 4. Wonamifull Citamiang nature tourism center

Tourism developed by LMDH Puncak Lestari includes mountaineering tours in Puncak Kencana, camping tours, agro tea garden tours, lodging, room rentals and capacity building space. In addition, in the wonderful complex of Citamiang, additional facilities are built in the form of bathing pools and camping spaces. People can rent tents at a rate of IDR. 180,000 / unit / night with 2 beds or buildings IDR. 380,000 / room / night with 2 beds. The average LMDH member income is IDR. 13,387,500 / household / year or IDR. 1,115,600 / HH / month / person / year (Table 1).

Tugu Utara HPD Forest can have more value from environmental services when the parties can jointly manage well and carry out various environmentally friendly activities. Furthermore, the LMDH Puncak Lestari members agreed to apply for management for 35 
years. As a result, as many as 75 households received SK KULINKK from KLHK which was submitted to the community in February 2019.

\section{CONCLUSION}

This study concludes that the needs of household can be fulfilled from the coffee agroforestry income added with income from the forest-based tourism activities. This result has attracted the members of the Community Group who have not yet implemented the coffee agroforestry and tourism activities in Special Village's Forest, Tugu Utara Village to be involved in the business.

\section{ACKNOWLEDGEMENT}

We thank the LMDH Puncak Lestari, Indonesia Climate Change Trust Fund (ICCTF). The research grant supported by Hibah Publikasi Internasional Terindeks untuk Tugas Akhir Mahasiswa (PITTA) 2018 funded by the Directorate of Research and Community Engagement, University of Indonesia No. 2584/UN2.R3.1/HKP.05.00/2018 and also thanks to Pratita Atinirmala, S.Si for her support.

\section{REFERENCES}

[1] O. Soemarwoto. Bandung Djambatan (1985)

[2] S. Rusli, S. Widono, H. Indriana. Sodalit Journal, 3 1 (2009)

[3] N. Daldjoeni. Bandung : Alumni (1989)

[4] G.T. Svendsen, G. L. H. Svendsen. Edward Elgar Publishing Limited (2009)

[5] A.S. Cheng, V. E. Sturtevant. Springer Science Business Media, LLC (2011)

[6] R. Tiwari, L. Marina, S. Dianne. Springer ScienceBusiness Media Singapore (2014)

[7] GOI The Decree of Forestry and Environmental Ministry Number P.83/MENLHK/SETJEN/KUM.1/10/2016 about Social Forestry (2016)

[8] A.A. Pramono. Journal of Social and Forest Economic Research. 61 39-51 (2009)

[9] BPS. BPS Catalog: 1102001.3201 (2017)

[10] GOI. Presidential Decree Number 54 in 2008 About Area Spatial Planning in Jakarta, Bogor, Depok, Tangerang, Bekasi, Puncak, Cianjur (Jabodetabekpunjur) (2008)

[11] GOI. The Law Number 37 In 2014 About Land and Water Conservation (2014)

[12] P. Rajagukguk, E. Sribudiani, M. Mardhiansyah. Jom Faperta 22 (2015)

[13] Sudaryanto, T. O. Variasa. E3S Web Conferences 74, 09005 (2018)

[14] Perhutani. Forest Management with The Community (PHBM). Portal BUMN (2001)
[15] S. Shackleton, B. M. Campbell, E. Wollenberg, D. Edmunds. The Overseas Development Institute. London. (2002)

[16] M. Suparmoko M, M. Ratnaningsih, Second Printing BPFE Yogyakarta (2012)

[17] S. W. Utomo, R. Rizal. Edisi Kesatu. Universitas Terbuka. Jakarta (2006)

[18] C. Stangor. Baltimore. $5^{\text {th }}$ Ed. (2015)

[19] A. Angelsen, H.O. Larsen, J.F. Lund, S. Wunder, C. Smith-Hall. Bogor (2011)

[20] BPS. (2018)

[21] T. Waryono. Panel Discussion Forest and Land Rehabilitation Program For The Society Prosperity Around The Forest. (2009)

[22] H. Supriadi, Perspective 131 35-52 (2014)

[23] H. Supriadi,D. Pranowo, 14 2: 135-150 (2015)

[24] H. S. A. Br Karo Departemen Agribisnis Fakultas Pertanian, Universitas Sumatera Utara (2009) 